\title{
A neuroanatomically-based model for human color vision
}

\author{
Charles Q Wu \\ From Nineteenth Annual Computational Neuroscience Meeting: CNS*2010 \\ San Antonio, TX, USA. 24-30 July 2010
}

Presently there are two dominant theories for human color vision: Young-Maxwell-Helmholtz's trichromatic theory and Hering's opponent-color theory. It is widely purported that the trichromatic theory holds true for retinal color processing whereas the opponent-color theory works for cortical color processing. My purposes in the present paper are threefold: to demonstrate, based on both empirical and logical grounds, that the opponent-color theory is fundamentally untenable; to extend the trichromatic theory from retinal color processing to the cortical level; and to present a computational model based on neuroanatomical data for human color vision.

Empirically, the opponent-color theory is false because it runs against many lines of observational and experimental data. First of all, this theory claims that it is impossible for a human being to perceive red and green colors in the same place at the same time; now there have been several demonstrations (e.g., see [1] and [2]) clearly indicating that this assumption is unwarranted. Second, colors appearing in complementary afterimages and in color contrast conditions are complementary to stimulus colors-rather than opponent colors as the opponent theory supposes. Third, in the so-called flightof-colors phenomenon, the predominant colors are the complementary colors of three primary colors (red, green, and blue) embraced by the trichromatic theory, not the four unique hues (red, green, yellow, and blue) as assumed by the opponent-color theory. Logically, the opponent-color theory needs to postulate a neural mechanism for mixing colors between red and green colors which in turn needs to turn off neural activities along the red and the green cardinalities-it is simply impossible to realize such a mechanism in any physical system.

In contrast to the opponent-color theory, the trichromatic color theory can easily be extended to cortical color

Correspondence: charlesqwu@126.com

Stanford Continuing Studies, Stanford University, Stanford, CA 94305, USA processing. In fact, such a theoretical integration had been attempted by Rollett [3] and McDougall [4] more than a century ago-It is very unfortunate that their efforts had largely been forgotten. Here I attempt to use an extended Young-Maxwell-Helmholtz trichromatic theory to explain several color perception phenomena, including coexistence of red and green colors, both positive and negative afterimages, contrast colors, and flight-of-colors.

Based on the fact that many color phenomena are monocular, I further propose that, in the primate (including the humankind) visual system, lamina $4 \mathrm{C}$ in the primary visual cortex (V1) is the neural substrate for cortical trichromaticity-because this is the only cortical stage where neurons are predominantly monocular. I present a three-layer computational model to simulate the first three stages of human visual processing: the retina, the LGN, and layer 4C. By incorporating anatomical data of cell distributions and a scheme of neuronal population cardinality coding, the model can account for many essential features of trichromaticity: additive and subtractive color mixing, color complementarity in afterimages and in contrast colors, and color transparency.

\section{Conclusions}

In summary, I contend that the trichromatic theory can explain both retinal and cortical color processing and that the opponent-color theory is fundamentally erroneous. Furthermore, I suggest that the neuronal trichromatic stage directly corresponding to human color sensation is layer $4 \mathrm{C}$ in V1.

Published: 20 July 2010

\section{References}

1. Crane HD, Piantanida TP: On seeing reddish green and yellowish blue. Science 1983, 221:1078-1080.

2. Billock VA, Gleason GA, Tsou BH: Perception of forbidden colors in retinally stabilized equiluminant images: an indication of softwired 
cortical color opponency? J Opt Soc Am A Opt Image Sci Vis 2001,

18:2398-2403.

3. Rollett A: Zur Lehre von den Contrastfarben und dem Abklingen der Farben. Wien. Ber. Bd. S 1867, 55:424-432.

4. McDougall W: Some new observations in support of Thomas Young's theory of light- and colour-vision (II). Mind 1901, 10:210-245.

doi:10.1186/1471-2202-11-S1-P143

Cite this article as: Wu: A neuroanatomically-based model for human color vision. BMC Neuroscience 2010 11(Suppl 1):P143.

Submit your next manuscript to BioMed Central and take full advantage of:

- Convenient online submission

- Thorough peer review

- No space constraints or color figure charges

- Immediate publication on acceptance

- Inclusion in PubMed, CAS, Scopus and Google Scholar

- Research which is freely available for redistribution

Submit your manuscript at www.biomedcentral.com/submit 